\title{
Nano sized carbonized waste biomass for heavy metal ion remediation
}

\author{
Garima Mahajan*, Dhiraj Sud \\ Sant Longowal Institute of Engineering and Technology, Department of Chemistry, Longowal - 148106 \\ "Corresponding author: e-mail: garima8mahajan@hotmail.com
}

\begin{abstract}
Utilization of agricultural waste material with approach to enhance the heavy metal remediation properties by carbonizing the biomass at nano size particles has been explored in present investigation from aqueous solutions. In this study the lignocellulosic, nitrogenous agricultural waste biomass Delbergia sissoo pods (DSP) has been tried for sequestering of $\mathrm{Cd}$ (II), $\mathrm{Pb}$ (II) and $\mathrm{Ni}$ (II) metal ions from aqueous solutions. Batch experiments were performed for removal of targeted metal ions keeping in consideration the preliminary affecting parameters such as effect of adsorption dose, $\mathrm{pH}$, initial metal ion concentration, stirring speed and contact time. The sorption studies were analyzed by using, Freundlic isotherm and Langmuir isotherm models. The kinetics of the process was evaluated by pseudo pseudo-first order and pseudo second order kinetic models. Studies reveal that the equilibrium was achieved with in $30 \mathrm{~min}$ of the contact time at optimized parameters. Analytical studies of biosorbent were done by means of FT-IR, SEM and XRD. Desorption experiments were carried out using $\mathrm{HCl}$ solution with a view to regenerate the spent adsorbent and to recover the adsorbed metal ions.
\end{abstract}

Keywords: nitrogenous waste materials, carbon, heavy metal ions, kinetic studies, Delbergia sisso pods.

\section{INTRODUCTION}

Metals exist naturally in the earth's crust, and their contents in the environment can vary between different regions resulting in spatial variations of background concentrations. The distribution of metals in the environment is governed by the properties of the metal and influences of environmental factors ${ }^{1}$. Of the all 92 naturally occurring elements, approximately 30 metals and metalloids are potentially toxic to humans, $\mathrm{Be}, \mathrm{B}$, Li, Al, Ti, V, Cr, Mn, Co, Ni, Cu, As, Se, Sr, Mo, Pd, $\mathrm{Ag}, \mathrm{Cd}, \mathrm{Sn}, \mathrm{Sb}, \mathrm{Te}, \mathrm{Cs}, \mathrm{Ba}, \mathrm{W}, \mathrm{Pt}, \mathrm{Au}, \mathrm{Hg}, \mathrm{Pb}$, and $\mathrm{Bi}$. Heavy metals is the generic term for metallic elements having an atomic weight higher than 40.04 (the atomic mass of $\mathrm{Ca})^{2}$. Heavy metals enter the environment by natural and anthropogenic means. Such sources include: natural weathering of the earth's crust, mining, soil erosion, industrial discharge, urban runoff, sewage effluents, pest or disease control agents applied to plants, air pollution fallout, and a number of others ${ }^{2}$. Although some individuals are primarily exposed to these contaminants in the workplace, for most people the main route of exposure to these toxic elements is through the diet (food and water). The contamination chain of heavy metals almost always follows a cyclic order: industry, atmosphere, soil, water, foods and human. Although toxicity and the resulting threat to human health of any contaminant are, of course, a function of concentration, it is well-known that chronic exposure to heavy metals and metalloids at relatively low levels can cause adverse effects, 4, 5, 6, 7. Therefore, there has been increasing concern, mainly in the developed world, about exposures, intakes and absorption of heavy metals by humans. Populations are increasingly demanding a cleaner environment in general, and reductions in the amounts of contaminants reaching people as a result of increasing human activities. A practical implication of this trend, in the developed countries, has been the imposition of new and more restrictive regulations ${ }^{8,9}$. Thus considering the importance of the threat bioremediation by means of waste agricultural materials has gained the momentum due to their potential efficacy and cost suitability ${ }^{10,11,12}$. Agricultural waste materials being low operating cost, availability in abundance, effective in dilute solutions, generates minimum secondary waste, completes with in a short time period, unique chemical composition and more efficiency seem to be a viable option for heavy metal ion remediation. Biosorption is a process in which physico-chemical interaction between the charged surface groups of biosorbents and ions in solution takes place by the process of complexation, ion exchange, microprecipitation, chelation and chemisorptions etc ${ }^{11}$. Several investigations have been undertaken for the removal of heavy metal ions ions from wastewater using different low-cost agricultural waste materials such as Arachis hypogea, Acacia saligna ${ }^{12,13}$, cassia fistula biomass ${ }^{14}$, sugarcane bagasse ${ }^{15}$, waste tea leaves ${ }^{16}$, Wheat straw $^{17}$, black gram husk ${ }^{17}$ and saw dust of oak and black locust ${ }^{18}$. These agricultural wastes mainly consist of lignin, cellulose, hemi-cellulose, carbohydrates and some proteins that make them effective adsorbent for heavy metal ions. Biomaterials when used in natural form may lead to release of soluble organic materials and further, as they lack mechanical strength and have a wide size distribution, leads to the problems in the operations of reactors by blocking flow lines and clogging filters, while separation of biomass and effluent can be difficult and expensive. As the adsorption capacity of an adsorbent mainly depend upon its pore size, chemical composition (influencing its interaction with polar and non-polar adsorbates) and active sites which determine the type of chemical reactions with other molecules, commercial activated carbon emerged as a potential sequestering agent due to fast and effective results but the cost factor somewhere suppressed its utilization at the large scale. Thus use of local, natural, and cheap materials that are available in large quantities or certain waste from agricultural operations for treatment of water and wastewater containing heavy metals in developing countries is an area that is gaining interest. There are many studies in the literature relating to the preparation of carbon from various agricultural wastes materials such 
as sugar beet pulp, Sugarcane baggasse, fertilizer waste and olive waste cakes etc. and their application for the removal of lead, cadmium, zinc, copper, and nickel from water and wastewater ${ }^{19-25}$. Thus the objective of present study is to investigate the binding of metal ions by selected agricultural waste material in carbonized form from aqueous solutions and to study the effect of various factors affecting the efficiency of the process.

\section{METHOD AND MATERIAL}

\section{Preparation of Adsorbent}

The selected biosorbent Delbergia sisso pods (DSP) were collected from Sangrur region of India. Hot water treatment was given to them for one hour to remove the soluble organic components and dust, was dried at $120^{\circ} \mathrm{C}$ in hot air oven for $24 \mathrm{~h}$, grounded and sieved (150 MICS). The carbonized form of biomass was prepared by heating the powder of biomass in a muffle furnace at $800^{\circ} \mathrm{C}$ for two hours. To explore the number and positions of the functional groups available for the binding of metal ions on to the biomaterials, FT-IR spectra and XRD studies of native and metal loaded biomass and SEM studies were done to reveal the surface morphological characters of the biosorbent.

\section{Preparation of Adsorbate}

A stock solution of $\mathrm{Ni}$ (II), Cd (II) and $\mathrm{Pb}$ (II) were prepared $(1000 \mathrm{mg} / \mathrm{L})$ by dissolving desired amount of nickel nitrate, cadmium nitrate and lead nitrate in $1 \mathrm{~L}$ of de-ionized water. The stock solution was diluted with de-ionized millipore water to obtain the desired concentration range of metal ion solutions. The concentration in the test solutions was determined spectro photometrically using Double Array UVVIS Spectrophotometer, (Agilent 8453) at a wavelength corresponding to the maximum absorbance for particular metal ion for Ni (II), Cd (II) and $\mathrm{Pb}$ (II). $\mathrm{pH}$ of the solutions were adjusted using 0.1 $\mathrm{m} \mathrm{mol} / \mathrm{L} \mathrm{HCl}$ or $\mathrm{NaOH}$ using Orion $420 \mathrm{~A} \mathrm{pH}$ meter. All the used chemicals were of Analytical grade. The experiments were performed in duplicates and after the simulated experiments; studies were also carried out on real industrial effluents. Composition of the industrial wastewater is given in Table 1.

Table 1. Characterization of Industrial effluent

\begin{tabular}{|l|c|}
\hline Parameters & Amount in Effluent \\
\hline $\mathrm{pH}$ & 4.33 \\
\hline Temperature & $22.8^{\circ} \mathrm{C}$ \\
\hline Electric Conductivity & $65.5 \mathrm{mS}$ \\
\hline Salinity & $43.4 \%$ \\
\hline Total Solids & $76000 \mathrm{mg} / \mathrm{l}$ \\
\hline Total dissolved solids & $63000 \mathrm{mg} / \mathrm{l}$ \\
\hline BOD & $290 \mathrm{mg} / \mathrm{l}$ \\
\hline $\mathrm{COD}$ & $312.6 \mathrm{mg} / \mathrm{l}$ \\
\hline $\mathrm{Sulphide}$ & $1.35 \mathrm{mg} / \mathrm{l}$ \\
\hline $\mathrm{TKN}$ & $210.14 \mathrm{mg} / \mathrm{l}$ \\
\hline $\mathrm{Cr}($ Total $)$ & $1500 \mathrm{mg} / \mathrm{l}$ \\
\hline $\mathrm{Cr}(\mathrm{VI})$ & $\mathrm{BDL}$ \\
\hline $\mathrm{Ca}$ & $152 \mathrm{mg} / \mathrm{l}$ \\
\hline $\mathrm{Cu}$ & $0.1 \mathrm{mg} / \mathrm{l}$ \\
\hline $\mathrm{Cd}$ & $0.012 \mathrm{mg} / \mathrm{l}$ \\
\hline $\mathrm{Ni}$ & $1.152 \mathrm{mg} / \mathrm{l}$ \\
\hline $\mathrm{Pb}$ & $15.26 \mathrm{mg} / \mathrm{l}$ \\
\hline $\mathrm{Zn}$ & $0.793 \mathrm{mg} / \mathrm{l}$ \\
\hline
\end{tabular}

\section{Adsorption Experiments}

Adsorption experiments were carried out by using 100 $\mathrm{ml}$ of metal solution of varying concentration $(5-500 \mathrm{mg} / \mathrm{l})$ at varying initial $\mathrm{pH}(2-7)$ with different stirring speed (50-300), contact time (5-120 min) having varying adsorbent dose (50-1000 mg) in $250 \mathrm{ml}$ Erlenmeyer flask at room temperature. Samples were separated by centrifugation at $4000 \mathrm{rpm}$ for $10 \mathrm{~min}$. The residual metal ion concentration was determined as mentioned in APHA, $1995^{\mathbf{2 6}}$. The removal percentage ( $\left.\mathrm{R} \%\right)$, defined as the ratio of difference in metal concentration before and after adsorption $\left(\mathrm{C}_{\mathrm{i}}-\mathrm{C}_{\mathrm{e}}\right)$ to the initial concentration of metal in the aqueous solution $\left(\mathrm{C}_{\mathrm{i}}\right)$, was calculated using equation (1)

$R \%=\left(\frac{C_{i^{0}}-C_{e}}{C_{i}}\right) \times 100$

\section{RESULTS AND DISCUSSION}

In terms of their structure, Dalbergia sissoo pods (DSP) can be regarded as a ligno-cellulosic agricultural waste material containing high amount of proteins and crude fibers. The pods are extremely rich in the nitrogenous substances containing various functional moieties for sequestering of heavy metal ions. The mechanism of metal ion removal by ligno-cellulosic biomass is attributed to anionic adsorption or by reduction of metals by ligno-cellulosic biomass. The contributing functional groups such as $\mathrm{N}-\mathrm{H}$ (amines) phenolic methoxyl and hydroxyl groups of lignin are responsible for metal ion reduction when tried in natural form and the oxidation of these functional groups gives rise to the formation of carbonyl and carboxyl groups of ligno-cellulosic material. But in carbonized form surface complexes were dominating as no major changes were observed in the peaks relating the amines and methoxyl groups. FT-IR analysis of adsorbents in carbon form before and after sorption of metal ions was performed to determine the vibrational frequency changes in the functional groups of the adsorbents. The spectra of adsorbent were measured in the range of $500-4000 \mathrm{~cm}^{-1}$ wave number (Fig. $1 \mathrm{a}, \mathrm{b}$, c, d). XRD studies reveal the regular pore spacing and pore size of the particles and the size of particles lies in the nano scale (Fig. 2 a, b, c, d). Further SEM images reveal the surface morphology of the biosorbent giving information regarding the surface texture and porosity of the DSPC. The images explores that the particles have a very narrow size distribution, with large availability of surface areas as sites for the metal ion adsorption (Fig. $3 \mathrm{a}, \mathrm{b}, \mathrm{c}, \mathrm{d})$.

\section{Effect of pH}

$\mathrm{pH}$ is an essential controlling parameter in the adsorption process due to its influence on the surface properties of the adsorbent and the ionic form of the metal ion in solution. Adsorption studies were carried out in the $\mathrm{pH}$ range of 1 to 7 , keeping all the parameters constant (Ni concentration - $50 \mathrm{mg} \mathrm{L}^{-1}$, stirring speed - $150 \mathrm{rpm}$, contact time - $30 \mathrm{~min}$, adsorbent dose $-0.5 \mathrm{~g} \mathrm{~L}^{-1}$ for DSPC at room temperature.The $\mathrm{pH}$ of the metal solution was adjusted after adding the adsorbent. The maximum adsorptions of $\mathrm{Ni}$ (II), Cd (II) and $\mathrm{Pb}$ (II) was 95\%, $95 \%$ 
a)

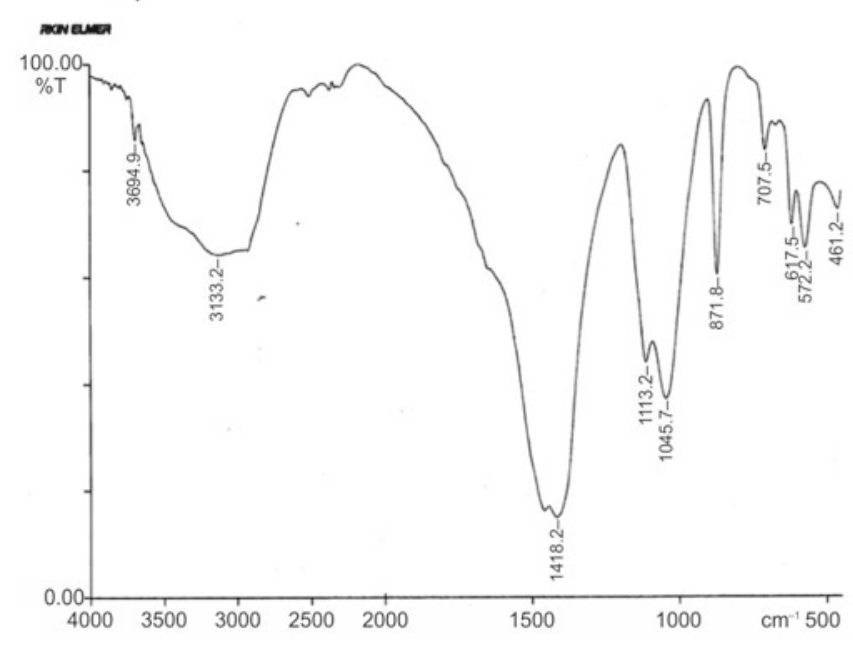

c)

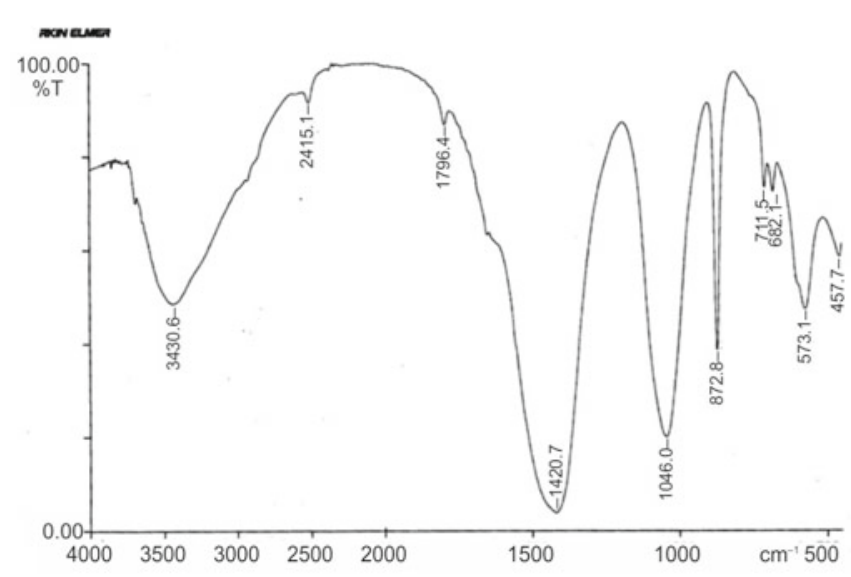

b)

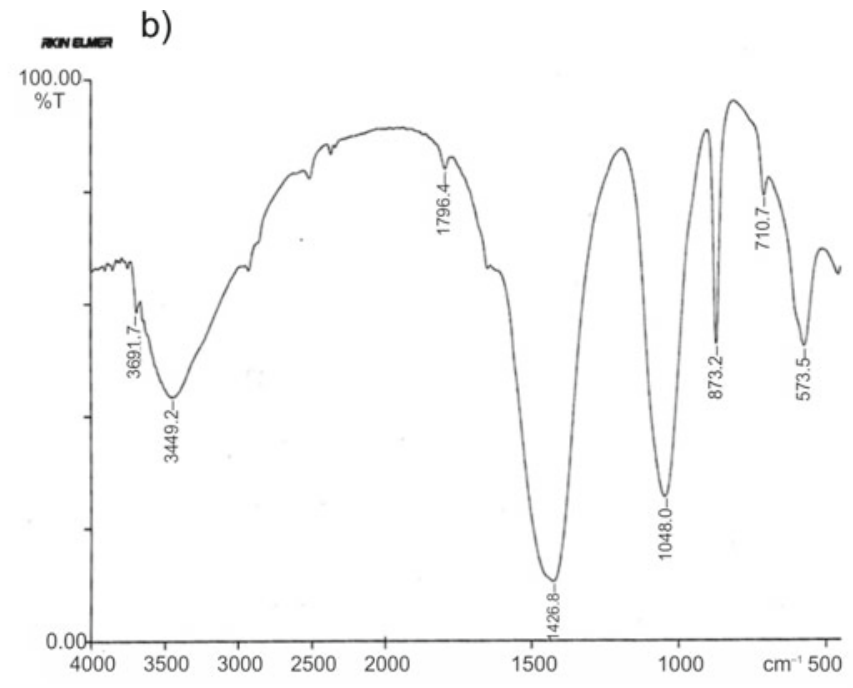

d)

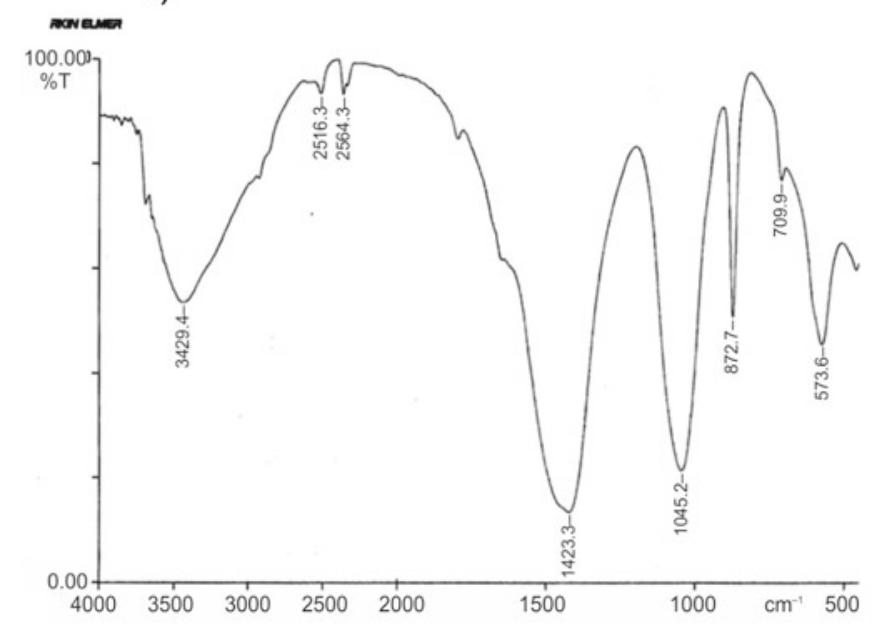

Figure 1. a) FT-IR spectra of native DSPC; b) FT-IR spectra of Cd (II) loaded DSPC; c) FT-IR spectra of Pb (II) loaded DSPC; d) FT-IR spectra of Ni (II) loaded DSPC

and $98 \%$ respectively at $\mathrm{pH} 6$ for $\mathrm{Ni}$ (II) and at $\mathrm{pH} 5$ for $\mathrm{Cd}$ (II) and $\mathrm{Pb}$ (II). It was observed that when the $\mathrm{pH}$ increased from 1.0 to 6.0 , the adsorption efficiency was increased remarkably resulting in to maximum removal efficiency of $95 \%$ for $\mathrm{Ni}$ (II) and Cd (II) and $98 \%$ for $\mathrm{Pb}$ (II) therefore, it was taken as the optimized $\mathrm{pH}$ value for further adsorption experiments (Fig. 4). It was observed that there was no significant enhancement in the removal efficiency of the biosorbent increasing $\mathrm{pH}$ further and after $\mathrm{pH} 7$ precipitation of the solution was observed. On the basis of simulated studies, real industrial effluent containing metal ions was taken from the electroplating industry, and studies were performed to determine the feasibility of the process on the real effluents. The removal efficiency was found to be near $100 \%$ for all the metal ions for selected biosorbent in carbonized form. The $\mathrm{pH}$ dependence of metal adsorption is largely related to the type and ionic state of the functional groups present on the adsorbent and the metal chemistry of the solution. At lower $\mathrm{pH}$ values, the $\mathrm{H}_{3} \mathrm{O}^{+}$ions compete with the metal ions for the exchange sites in the sorbent. As $\mathrm{pH}$ increases from the acidic range to the neutral range, $\mathrm{Ni}$ (II), $\mathrm{Cd}$ (II) and $\mathrm{Pb}$ (II) are present predominantly as $\mathrm{Ni}^{2+}, \mathrm{Cd}^{2+}$ and $\mathrm{Pb}^{2+}$. Moreover, due to the presence of vacant hydroxyl $(-\mathrm{OH}-)$ and carbonyl $(\mathrm{C}=\mathrm{O})$ groups, the formation of coordination complexes with the metal ion also occur. At low $\mathrm{pH}$ values, the $\mathrm{H}_{3} \mathrm{O}^{+}$ions compete with the metal ions for the binding sites of the DSPC, leaving the metal ions in solution. As the $\mathrm{pH}$ increases, the concentration of $\mathrm{H}_{3} \mathrm{O}^{+}$ions decreases and the sites on the DSPC surface become available for the metallic ions in the solution. Our results were found to be consistent with other studies that demonstrated that the removal of these metal ions decreases with a decrease in $\mathrm{pH}$ to 1.0 as shown by Mahajan et. al. 2012 and Garg et. al. 2008.

\section{Effect of Adsorbent Dose}

The adsorption of metal ions was studied at different adsorbent doses (50 to $500 \mathrm{mg}$ ) for with DSPC for selected metal ions, keeping metal ion concentration (50 $\mathrm{mg} \mathrm{L}^{-1}$ ), stirring speed (150 rpm), $\mathrm{pH}$ (5 for Cd (II) and $\mathrm{Pb}(\mathrm{II})$ and 6 for (Ni (II)), room temperature and contact time $(30 \mathrm{~min})$ constant. It was observed from the kinetics study that most of the metal ion removal by DSPC was achieved in $30 \mathrm{~min}$, so these experiments were conducted at $30 \mathrm{~min}$ of contact time. There was a constant increase in the adsorption of metal ions with an increase in the adsorbent dose. The increase in the adsorption with adsorbent dose may be due to the increase in adsorbent surface area and availability of more adsorption sites (Fig. 5). Similar trends have 
a)

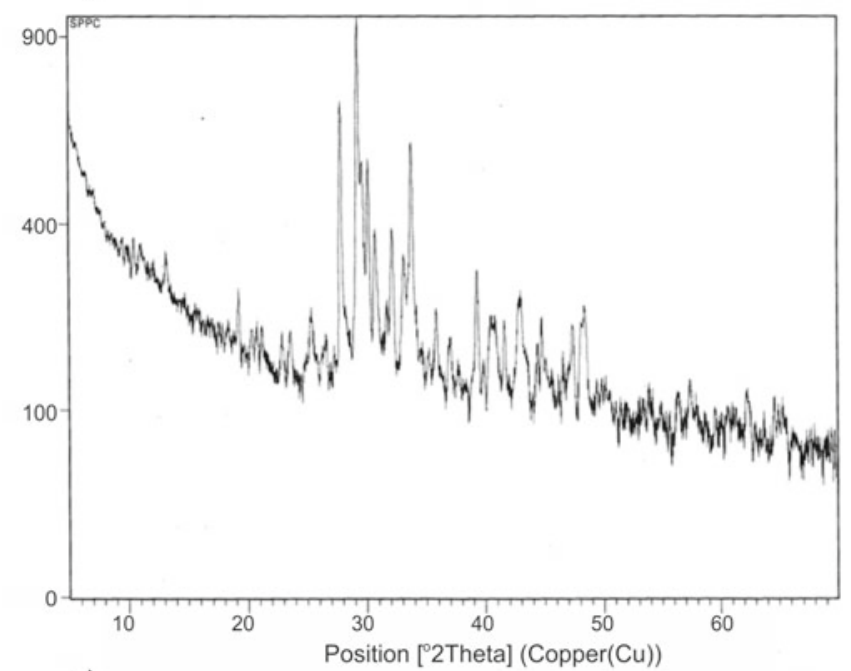

c)

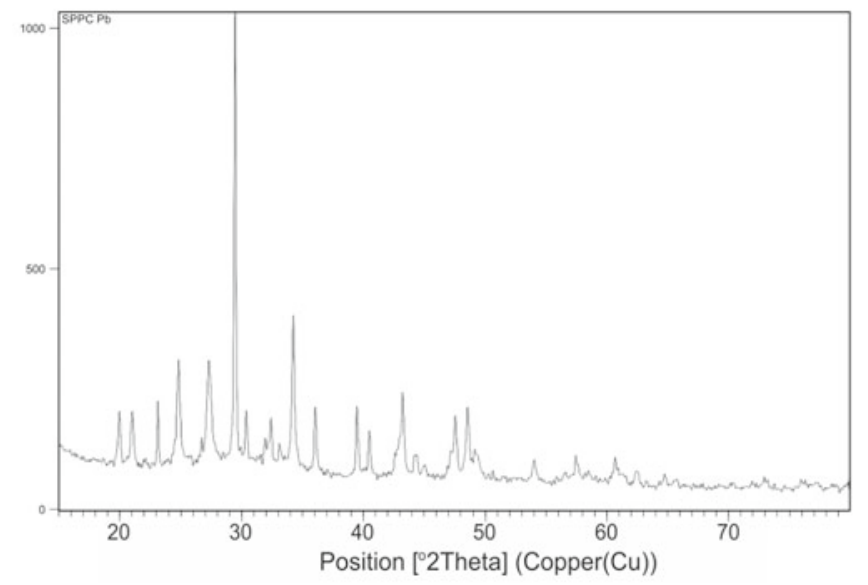

b)

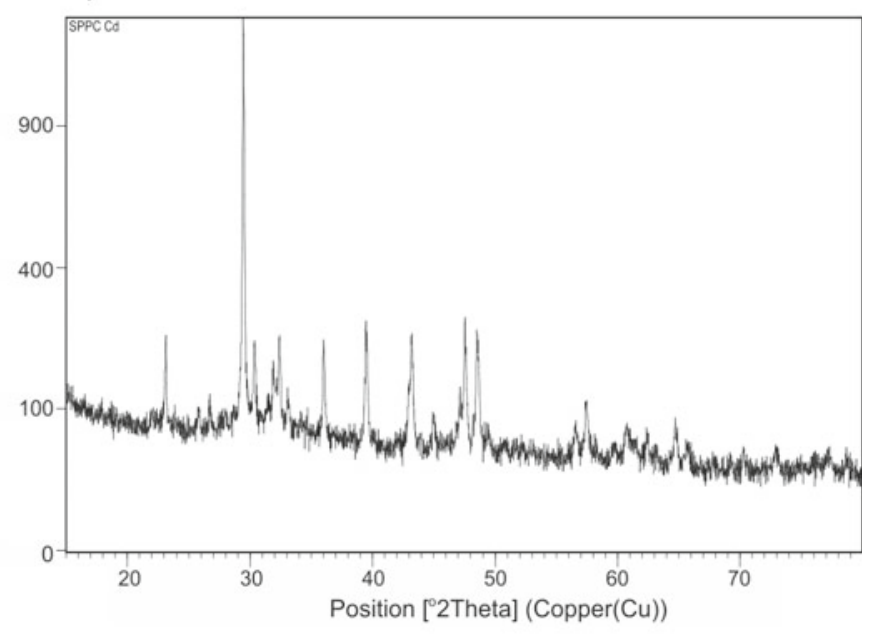

d)

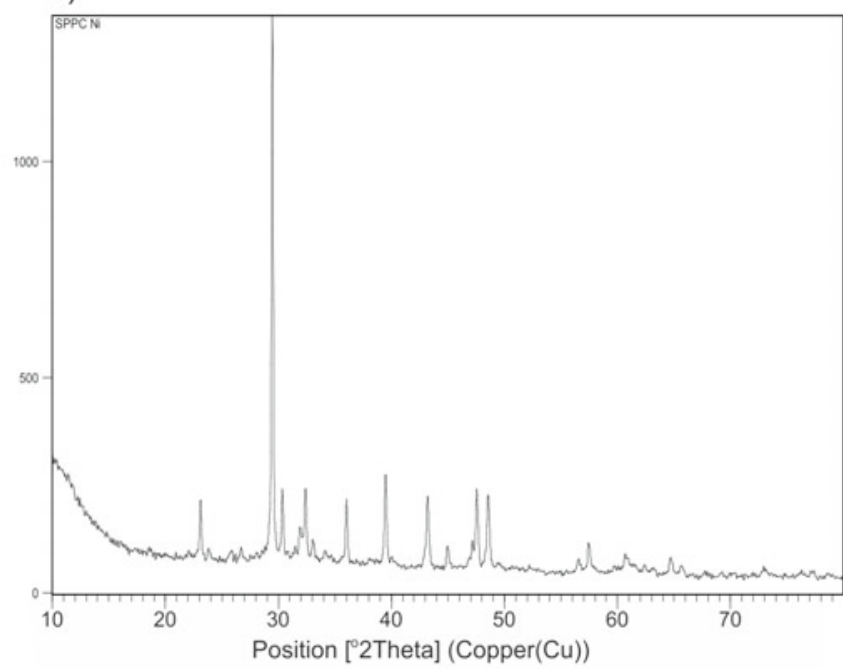

Figure 2. a) XRD pattern of native DSPC; b) XRD pattern of Cd (II) loaded DSPC; c) XRD pattern of Pb (II) loaded DSPC; d) XRD pattern of Ni (II) loaded DSPC

been found by Das et. al., 2007 and Mahajan and Sud, 2012 and $2011^{27,28,29}$.

\section{Effect of Contact Time/ Kinetics Studies}

Kinetics studies play a key role in finding the equilibrium during a reaction. Studies on carbonized form of adsorbent were conducted by varying the contact time from 5 to $60 \mathrm{~min}$ at a fixed metal ion concentration (50 $\left.\mathrm{mg} \mathrm{L}^{-1}\right)$, stirring speed (150 rpm), room temperature and $\mathrm{pH}$ (5 and 6). Maximum metal ions were sequestered from the solution in $30 \mathrm{~min}$ by DSPC. The Ni (II) and $\mathrm{Cd}$ (II) removal was 95 and $98 \%$ for $\mathrm{Pb}$ (II) in $30 \mathrm{~min}$ of contact time, respectively (Fig. 6). The results shown are in trend as shown by various researchers ${ }^{12,13,30,31}$.

\section{Effect of Initial Concentration}

The initial concentration of the industrial solution is a major parameter. Considering the possible concentration of heavy metals that can be discharged, a wide range of metal ion concentrations has been selected from $5 \mathrm{ppm}$ to $500 \mathrm{ppm}$. The adsorption of metal ions with DSPC was studied by varying the initial concentration $(5,10$, $25,50,75,100,250$ and $500 \mathrm{mg} \mathrm{L}^{-1}$ ) and keeping the adsorbent dose (500 $\left.\mathrm{mg} \mathrm{L}^{-1}\right)$, stirring speed (150 rpm), $\mathrm{pH}(5$ and 6$)$ and contact time of 30 minutes constant (Fig. 7). The purpose of using a higher concentration of metal ions was to study the maximum adsorption capacity of the adsorbent ${ }^{27}$. The experimental results showed that metal ion adsorption decreased with an increase in initial metal ion concentration. However, the actual amount of metal adsorbed per unit mass of the adsorbent increased with an increase in the initial concentration in the test solution.

\section{Adsorption Isotherms}

The experimental results obtained for the adsorption of metals on DSPC at a constant room temperature $\left(25 \pm 1^{\circ} \mathrm{C}\right)$ under predefined conditions of $\mathrm{pH}$, adsorbent dose, and stirring speed obeyed the Freundlich adsorption isotherm. The Freundlich adsorption isotherm represents the relationship between the amount of metal adsorbed per unit mass of the adsorbent $(\mathrm{x} / \mathrm{m})$ and the concentration of the metal ion in solution at equilibrium $\left(C_{e}\right)^{12}$.

$\log \frac{x}{m}=\log K_{f}+\frac{1}{n} \log C_{e}$

Where $K_{f}\left(\mathrm{~L} \mathrm{~g} \mathrm{~g}^{-1}\right)$ is an indicator of adsorption capacity and $n$ (dimensionless) indicates the effect of the concentration on the adsorption capacity and represents the adsorption intensity (dimensionless). The plot of log $(\mathrm{x} / \mathrm{m})$ versus $\log \left(C_{e}\right)$ for various initial concentrations was linear, indicating the applicability of the classical 
a)

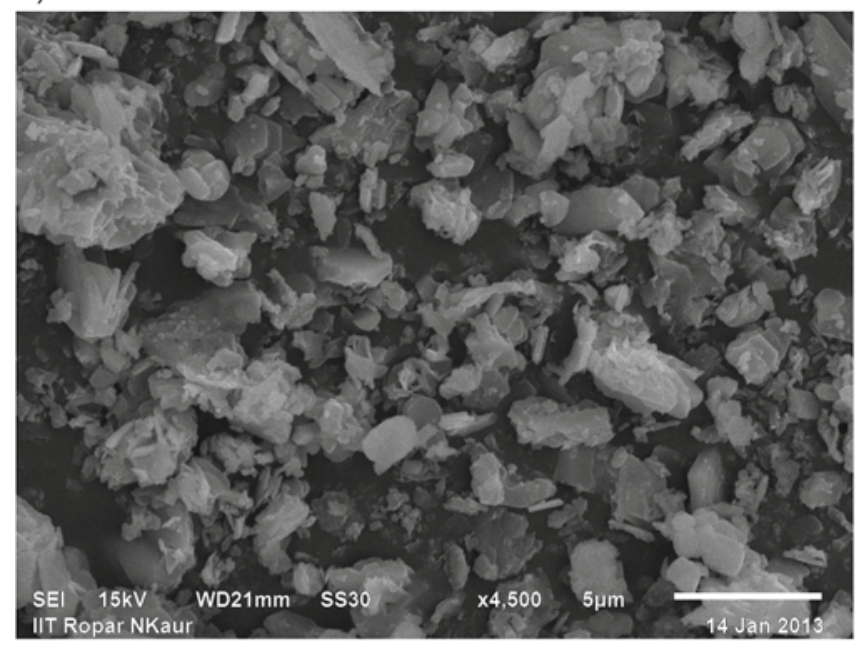

c)

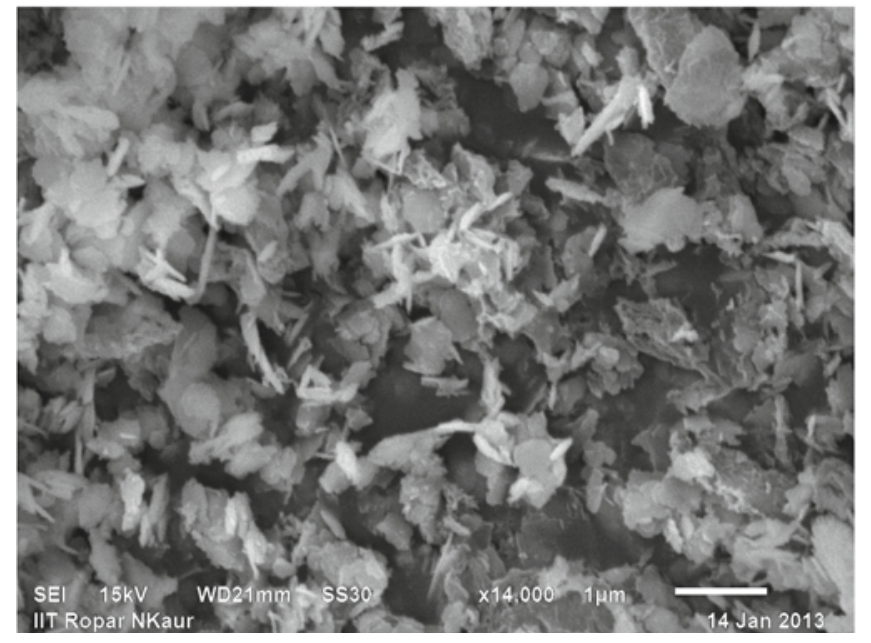

b)

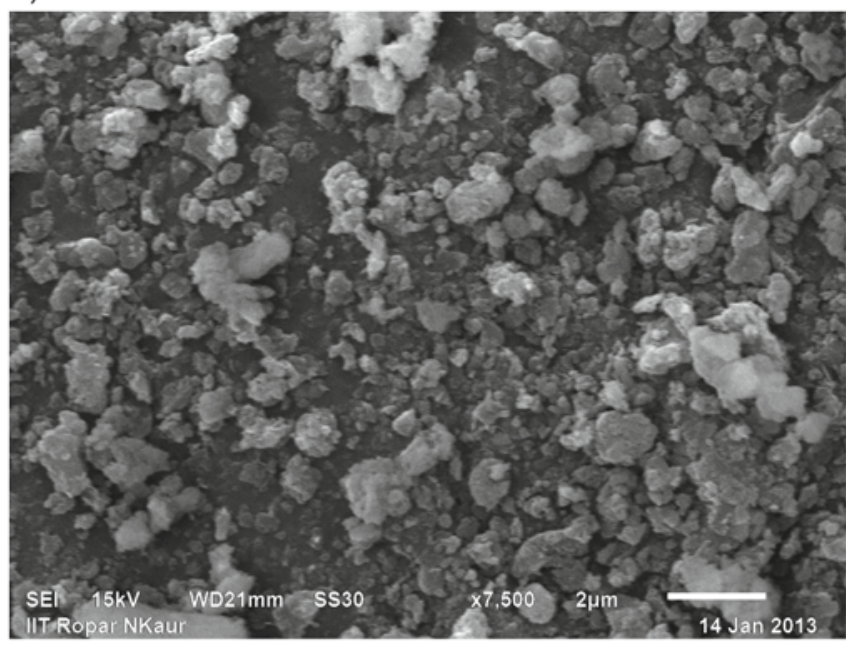

d)

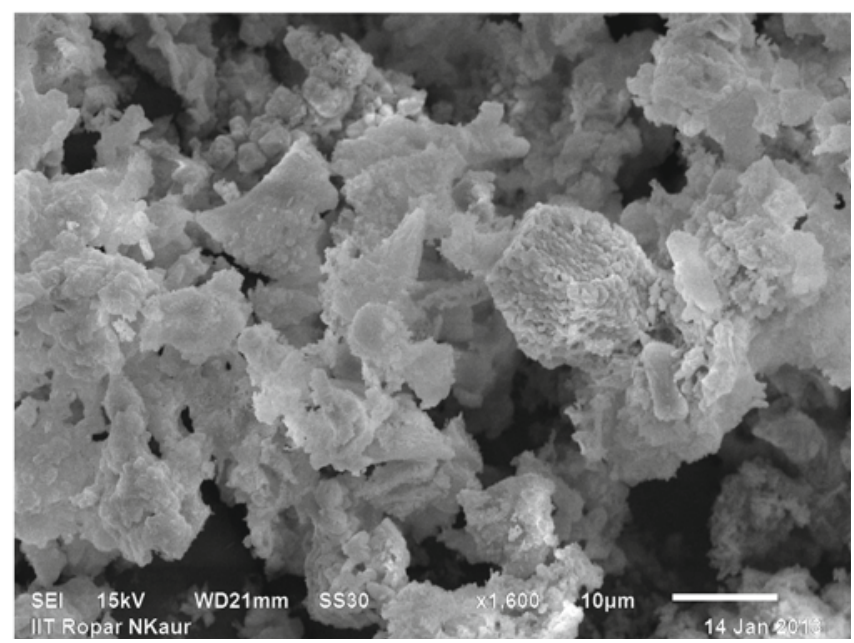

Figure 3. a) SEM of native DSPC; b) SEM of Cd (II) loaded DSPC; c) SEM of Pb (II) loaded DSPC; d) SEM of Ni (II) loaded DSPC

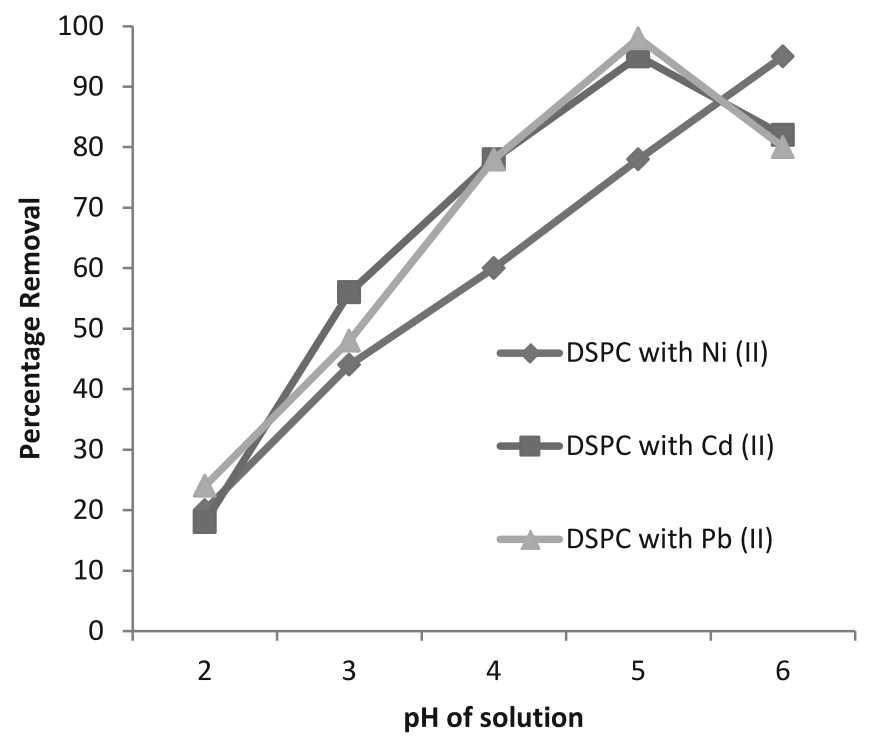

Figure 4. Effect of $\mathrm{pH}$ on removal efficiency of heavy metal ions (Ni (II), Cd (II) and $\mathrm{Pb}$ (II)

adsorption isotherm to the DSPC-Ni (II), DSPC- Cd (II) and DSPC- Pb (II) systems.

The Langmuir isotherm is applicable for monolayer adsorption onto a surface containing a finite number of identical sites. The model assumes uniform energies

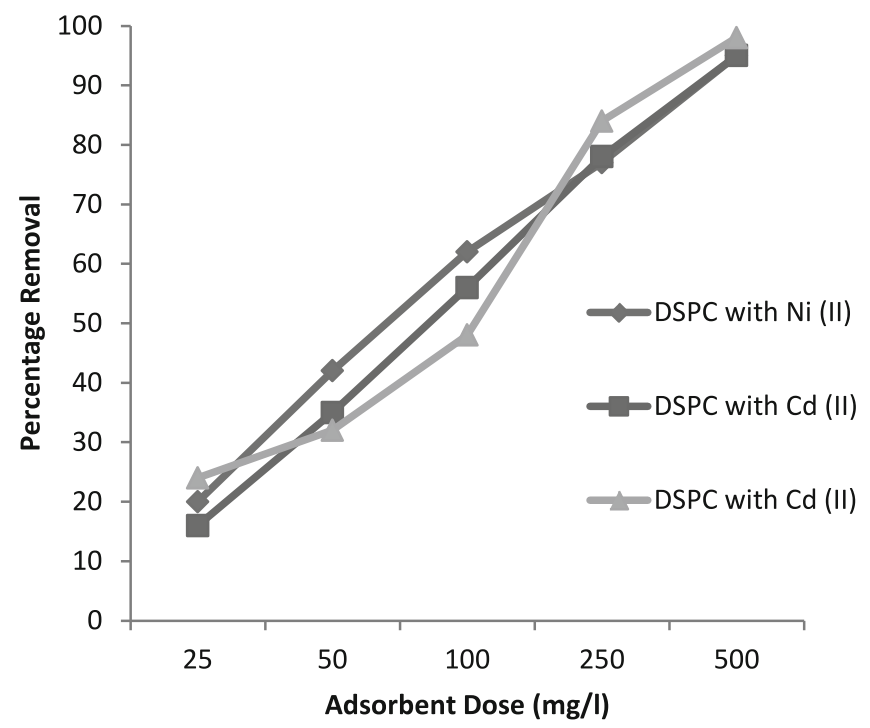

Figure 5. Effect of adsorbent dose $\mathrm{mg} \mathrm{L}^{-1}$ on removal efficiency of heavy metal ions (Ni (II), Cd (II) and Pb (II)

of adsorption on to the surface and no transmigration of adsorbate in the plane of the surface. The Langmuir isotherm is represented by the following equation.

$\frac{C_{e}}{q_{e}}=\frac{1}{Q_{o} b}+\frac{C_{e}}{Q_{o}}$ 


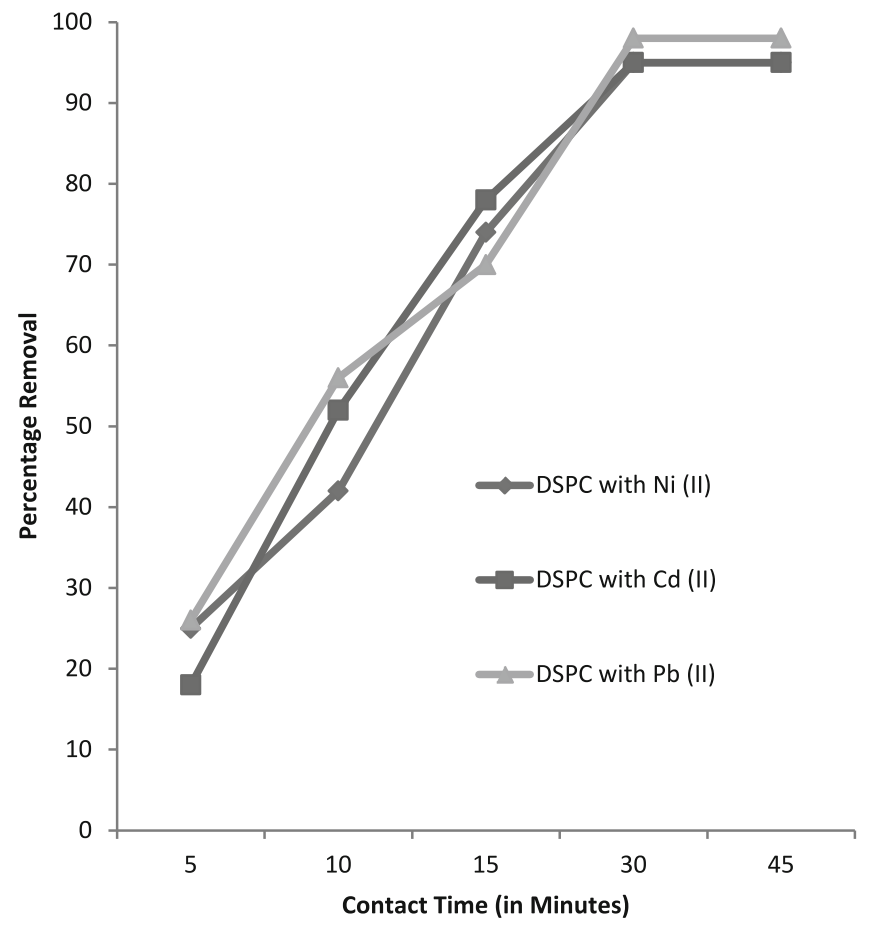

Figure 6. Effect of contact time (min) on removal efficiency of heavy metal ions (Ni (II), Cd (II) and Pb (II)

where $C_{e}$ is the equilibrium concentration $\left(\mathrm{mg} \mathrm{L}^{-1}\right), q_{e}$ is the amount adsorbed at equilibrium time $\left(\mathrm{mg} \mathrm{g}^{-1}\right), \mathrm{Q}_{\mathrm{o}}$ is the maximum quantity of metal ions per unit weight of biomass to form a complete monolayer on the surface $\left(\mathrm{mg} \mathrm{g}^{-1}\right)$, and $b$ is a constant related to the affinity of binding sites with the metal ions $\left(\mathrm{L} \mathrm{mg}^{-1}\right)^{32,33}$. The plots of $C_{e} /(\mathrm{x} / \mathrm{m})$ versus $C_{e}$ are linear, which shows that the adsorption of metal ions follows the Langmuir isotherm model. The correlation coefficient $\left(\mathrm{R}^{2}\right)$ values were very high for selected Adsorbent, which indicates that the data fit reasonably well to the Langmuir isotherm in the present adsorption studies. The value of the slope was found to be less than unity, implying that significant adsorption took place at a low metal ion concentration (Table 2).

\section{ADSORPTION KINETICS}

\section{Pseudo $1^{\text {st }} \& 2^{\text {nd }}$ order equations}

For evaluating the adsorption kinetics of heavy metals the pseudo-first order equation of lagergren has been used to test experimental data.

$\ln \left(Q_{e}-Q_{t}\right)=\ln Q_{e}-K_{l} t$

where $Q_{e}(\mathrm{mg} / \mathrm{g})$ and $Q_{t}(\mathrm{mg} / \mathrm{g})$ are the amount adsorbed of heavy metal ions at equilibrium and at time $t$, respectively, and $K_{1}\left(\mathrm{~min}^{-1}\right)$ is the rate constant of pseudo $1^{\text {st }}$ order adsorption. The model was found inapplicable when this equation is fitted to the data of the selected agricultural waste biosorbent for the removal of heavy metal ions with $\mathrm{R}^{2}$ value very low.

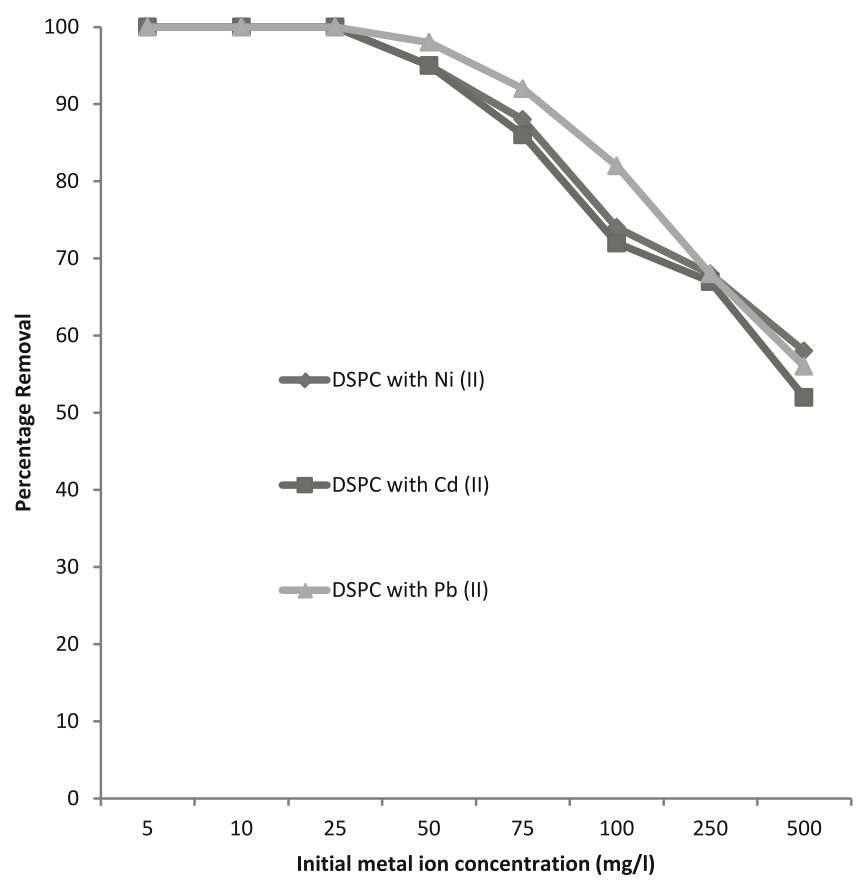

Figure 7. Effect of initial metal ion concentration $\mathrm{mg} \mathrm{L}^{-1}$ on removal efficiency of heavy metal ions (Ni (II), $\mathrm{Cd}$ (II) and $\mathrm{Pb}(\mathrm{II})$ )

The pseudo $2^{\text {nd }}$ order kinetic model is linearly expressed as $^{34}$ :

$t / Q_{t}=1 / K_{2} Q_{e}^{2}+t / Q_{e}$

Where $\mathrm{K}_{2}(\mathrm{~g} / \mathrm{mg} \min )$ is the pseudo $2^{\text {nd }}$ order rate constant, which can be calculated from the intercept of the straight line obtained from plotting $t / Q_{t} V s$. Also, the initial sorption rate can be calculated using the relation ${ }^{35}$ : $K_{o}=K_{2} Q_{e}^{2}$

The perfect fit of the experimental data of DSPC indicates the applicability of model for the adsorption of heavy metal ions on the DSPC.

\section{Real Industrial Effluent Treatment}

Results grafted from the previous optimization experiments were used to conduct the experiments with real industrial effluents of electroplating industry. It has been found that percentage removal efficiency was good when the biosorbent was used for treatment of real industrial effluents. For single metal simulated solutions the removal efficiency of DSPC for Ni (II) and Cd(II) has been found $95 \%$, and $98 \%$ for $\mathrm{Pb}$ (II) respectively and the removal efficiency of DSPC has been found to be nearly $100 \%$ for $\mathrm{Ni}(\mathrm{II}), \mathrm{Cd}(\mathrm{II})$ and $\mathrm{Pb}$ (II) for selected real industrial effluents. Enhanced removal efficiency is due to the reason that as simulated solutions concentration is $50 \mathrm{ppm}$ and the concentration of metal ions in real industrial effluent is very less therefore better removal efficiency has been found in latter.

Table 2. Freundlich and Langmuir models regression constants for different adsorbent

\begin{tabular}{|c|c|c|c|c|c|c|}
\hline Adsorbent & \multicolumn{3}{|c|}{ Freundlich isotherm } & \multicolumn{3}{|c|}{ Langmuir isotherm } \\
\hline & $\begin{array}{c}K_{f} \\
\left(1 g^{-1}\right)\end{array}$ & $\mathrm{N}$ & $\mathrm{R}^{2}$ & $\begin{array}{c}Q_{0} \\
\left(\mathrm{mg} \mathrm{g}^{-1}\right)\end{array}$ & $\begin{array}{c}\mathrm{B} \\
\left(1 \mathrm{mg}^{-1}\right)\end{array}$ & $\mathrm{R}^{2}$ \\
\hline DSPC with $\mathrm{Ni}$ (II) & 0.82 & 3.15 & 0.9421 & 0.62 & 0.030 & 0.9812 \\
\hline DSPC with $\mathrm{Pb}(\mathrm{II})$ & 0.87 & 3.35 & 0.9867 & 0.66 & 0.0311 & 0.9923 \\
\hline
\end{tabular}




\section{Desorption Efficiency and Reusability}

The reusability of the biosorbent is one of the key factors in assessing of its potential for commercial applications. Two different potential desorption agents ( $1 \mathrm{M} \mathrm{HCl}$ and $1 \mathrm{M} \mathrm{HNO}_{3}$ ) were used to desorbe the selected metal ions from the biosorbent. The desorption efficiency of $\mathrm{Ni}$ (II) was found to be $93 \%$ using $1 \mathrm{M} \mathrm{HCl}$ and $1 \mathrm{M} \mathrm{HNO}_{3}$ respectively. Similarly Cd (II) desorption was found to be $96 \%$ and $95 \%$ for $\mathrm{Pb}$ (II) respectively. Therefore, $1 \mathrm{M} \mathrm{HCl}$ solution was selected as desorption agent. The greater and faster desorption resulted due to surface binding of metal ions. The reusability of the biosorbent was also tested up to 5 consecutive sorption-desorption cycles. The results showed that the biosorbent offers potential ability to be used repeatedly in metal ion sequestering process.

\section{CONCLUSION}

The present study concluded that the DSPC has potentially higher adsorption efficiency for $\mathrm{Ni}$ (II), $\mathrm{Cd}$ (II) and $\mathrm{Pb}$ (II) under studied experimental conditions on simulated as well as for real industrial effluents. The metal ion removal was highly dependent on $\mathrm{pH}$, initial concentration and adsorbent dose. DSPC is found to be very effective and explores the promising platform for the sequestering of heavy metal ions as it outweigh the various shortcomings that are being encountered during the experimental process with biomass in its natural form. Further reusability of the biosorbent enhance its possibility to be utilized again and desorption studies makes the whole process environment friendly as the metal ions are not entering in the environment in the form of solid sludge and contaminating the aquatic systems. Delbergia sisso pods are one of the readily available agricultural wastes in India, especially in Punjab as the tree is declared as 'State tree' and its cultivation comes under agro-forestry and social forestry programmes. So it can be used by small scale industries having low concentrations of heavy metal ions in wastewater using batched or stirred-tank flow reactors in carbonized form.

\section{LITERATURE CITED}

1. Khlifi, R. \& Hamza-Chaffai, A. (2010). Head and neck cancer due to heavy metal exposure via tobacco smoking and professional exposure: A review. Toxicol. Appl. Pharma. 248, 71-88. DOI: 10.1016/j.taap.2010.08.003.

2. Ming-Ho, Y. (2005). Environmental Toxicology: Biological and Health Effects of Pollutants, Chap. 12, CRC Press LLC, 2nd Edition, BocaRaton, USA. DOI: 10.5271/sjweh.1888.

3. Agency for Toxic Substance and Disease Registry (ATSDR). (2003b). Toxicological Profile for Mercury U.S. Department of Health and Humans Services, Public Health Humans Services, Centers for Diseases Control. Atlanta.

4. Agency for Toxic Substances and Disease Registry (ATSDR). (2004). Toxicological Profile for Copper. U.S. Department of Health and Humans Services, Public Health Service, Centers for Diseases Control. Atlanta.

5. Agency for Toxic Substance and Disease Registry (ATSDR). (2007). Toxicological Profile for Lead U.S. Department of Health and Humans Services, Public Health Humans Services, Centers for Diseases Control. Atlanta.

6. Agency for Toxic Substance and Disease Registry (ATSDR). (2008). Draft Toxicological Profile for Cadmium U.S. Depart- ment of Health and Humans Services, Public Health Humans Services, Centers for Diseases Control. Atlanta.

7. Castro-González, M.I. \& Méndez-Armenta, M. (2008). Heavy metals: Implications associated to fish consumption. Environ. Toxico. Pharma. 26, 263-271. DOI: 10.1016/j.etap.2008.06.001.

8. European Commission. (2006). Regulation (EC) No 1881/2006. JO L364, 20.12.06, 5-24.

9. Figueroa, E. (2008). Are more restrictive food cadmium standards justifiable health safety measures or opportunistic barriers to trade? An answer from economics and public health. Sci. Total Environ., 389, 1-9.

10. Saeed, A. \& Iqbal, M. (2003). Bioremoval of Cd from aqueous solution by black gram husk (cicer arientinum). Water Res. 37, 3472-3480.

11. Sud, D., Mahajan, G. \& Kaur, M.P. (2008). Agricultural waste material as potential adsorbent for sequestering heavy metal ions from aqueous solutions - A review. Biores. Technol. 99, 6017-6027. DOI: 10.1016/j.biortech.2007.11.064.

12. Mahajan, G. \& Sud, D. (2011). Kinetics and equilibrium studies of chromium (VI) metal ion remediation by Arachis hypogea shells-A green approach. BioRes. 6(4), 3324-3338.

13. Mahajan, G. \& Sud, D. (2012). Modified agricultural waste biomass with enhanced responsive properties for metal ion remediation: a green approach. Appl. Water Sci. 2, 299-308. DOI: $10.1007 / \mathrm{s} 13201-012-0050-5$.

14. Hanif, M.A., Nadeem, R., Zafar, M.N., Akhtar, K., Bhatti, H.N. (2007). Nickel (II) biosorption by Cassia fistula biomass. J. Hazard. Mater. 139, 345-355. DOI: 10.1016/j.jhazmat.2006.06.040.

15. Garg, U.K., Kaur, M.P., Garg V.K. \& Sud, D. (2008). Removal of Ni (II) from aqueous solution by adsorption on agricultural waste biomass using a response surface methodological approach. Biores. Technol. 99, 1325-1331. DOI: 10.1016/j. biortech.2007.02.011.

16. Ahluwalia, S.S. \& Goyal, D. (2005). Removal of heavy metals from waste tea leaves from aqueous solution. Eng. Life Sci. 5, 158-162. DOI: 10.1002/elsc.200420066.

17. Malkoc, E. \& Nuhoglu, Y. (2005). Investigation of Ni (II) removal from aqueous solutions using tea factory waste. $\mathrm{J}$. $\mathrm{Ha}$ zard. Mater. 127, 120-128. DOI: 10.1016/j.jhazmat.2005.06.030.

18. Sciban, M., Klasnja, M. \& Skrbic, B. (2006). Modified hardwood sawdust as adsorbent of heavy metal ions from water. Wood Sci. Technol. 40, 217-227. DOI: 10.1007/s00226005-0061-6.

19. Bacaoui, A., Yaacoubi, A., Dahbi, A., Bennouna, C., Phan Tan Luu, R., Maldonado-Hodar, F.J., Rivera-Utrilla, J. \& Moreno-Castilla, C. (2001). Optimization of conditions for the preparation of activated carbons from olive-waste cakes. Carbon 39, 425-432. DOI: 10.1016/S0008-6223(00)00135-4.

20. Gupta, V.K., Mittal, A. \& Gajbe, V. (2005). Adsorption and desorption studies of a water soluble dye, quinoline yellow, using waste materials. J. Coll. Inter. Sci. 284, 89-98. DOI: 10.1016/j.jcis.2004.09.055.

21. Mohan, D., Gupta, V.K., Srivastava, S.K. \& Chander, S. (2001). Kinetics of mercury adsorption from wastewater using activated carbon derived from fertilizer waste. Coll. Surface. A 177, 169-181.

22. Mohan, D. \& Singh, K.P. (2002). Single- and multi-component adsorption of cadmium and zinc using activated carbon derived from bagasse-an agricultural waste. Water Res. 36, 2304-2318. DOI: 10.1016/S0043-1354(01)00447.

23. O"zer, A., Tanyildizi, M.S., Tu“men, F. (1998). Study of cadmium adsorption from aqueous solution on activated carbon from sugar beet pulp. Environ. Technol. 19, 1119-1126. DOI: 10.1080/09593331908616770.

24. Osvaldo Jr., K., Gurgel, Leandro Vinicius Alves, de Melo, Julio Cesar Perin, Vagner, R.B., Tania, M.S.M., de Freitas Gil, Rossimiriam Pereira, Gil, Laurent Frederic. (2007). Adsorption of heavy metal ion from aqueous single metal solution 
by chemically modified sugarcane bagasse. Biores. Technol. 98, 1291-1297. DOI: 10.1016/j.biortech.2006.05.013.

25. Mohsin, K., Anwar, R.S., Nadeem, F., Amir, Y. \& Ahmad, S.W. (2013). Removal of phenol from wastewater using activated waste tea leaves. Polish J. Chem. Technol. 15,1-6. DOI: 10.1007/s11814-011-0072-y. 16.

26. Standard Methods for the Examination of Water and Wastewater. (1995). ISBN 0-87553-207-1. American Public Health Association (16th ed.) Washington, DC.

27. Karthikeyan, T., Rajgopal, S. \& Miranda, L.R. (2005). Chromium (VI) adsorption from aqueous solution by Hevea brasilinesis sawdust activated carbon. J. Hazard. Mater. 124, 192-199. DOI: 10.1016/j.jhazmat.2005.05.003.

28. Naiya, T.K., Chowdhury, P.A., Bhattacharya, K., Das, S.K. (2009). Saw dust and neem bark as low-cost natural biosorbent for adsorptive removal of $\mathrm{Zn}$ (II) and Cd (II) ions from aqueous solutions. Chem. Engg. J. 148, 68-79.

29. Naiya, T.K.A., Bhattacharya, K. \& Das, S.K. (2009). Adsorption of $\mathrm{Cd}$ (II) and $\mathrm{Pb}$ (II) from aqueous solutions on activated alumina. J. Coll. Inter. Sci. 333 14-26. DOI: 10.1016/j. jcis.2009.01.003.

30. Naiya, T.K., Chowdhury, P.A., Bhattacharya, K. \& Das, S.K. (2009). Adsorptive removal of Cd (II) ions from aqueous solutions by rice husk ash. Environ. Progr. 28 535-546.

31. Naiya, T.K., Chowdhury, P.A., Bhattacharya, K. \& Das, S.K. (2008). Removal of Cd (II) from aqueous solutions using clarified sludge. J. Coll. Inter.W Sci. 325 48-56.

32. Goel, J., Kadirvelu, K., Rajagopal, C. \& Garg, V.K. (2005). Removal of lead (II) by adsorption using treated granular activated carbon: Batch and column studies. J. Hazard. Mater. 125, 211-220.

33. Bansal, M., Singh, D. \& Garg, V. K. (2009). A comparative study for the removal of hexavalent chromium from aqueous solutions by agricultural wastes carbons. J. Hazard. Mater. 171, 83-92. DOI: 10.1016/j.jhazmat.2009.05.124.

34. Ho, Y.S. \& Mackay, G. (1998). Kinetic models for the adsorption of dye from aqueous solutions by wood. J. Env. Sci. Health. 76, 183-187.

35. Koynucu, H. (2008). Adsorption kinetics of 3-hydroxybenzaldehyde on native and activated bentonite. Appl. Clay Sci. 38, 279-282. 